\title{
STATUS FUNGSIONAL PASIEN STROKE DI RUANG 5 RSUD DR SOEKARDJO KOTA TASIKMALAYA
}

\author{
Asep Robby ${ }^{1}$ \\ bee robby@yahoo.com \\ STIKes Bakti Tunas Husada Tasikmalaya \\ Selpiyati $^{2}$ \\ selpiy14@gmail.com \\ STIKes Bakti Tunas Husada Tasikmalaya
}

\begin{abstract}
Abstrak
Stroke merupakan kerusakan jaringan otak yang disebabkan oleh berkurangnya atau terhentinya suplai darah secara tiba-tiba. Disabilitas umum yang sering terjadi pada pasien stroke adalah kelumpuhan atau kelemahan pada satu sisi tubuh yang dapat menyebabkan gangguan fungsional. Status fungsional merupakan kemampuan individu untuk melakukan perawatan diri, pemeliharaan diri, dan aktivitas fisik dalam melakukan aktivitas sehari-hari. Tujuan penelitian ini adalah mengetahui gambaran status fungsional pasien stroke dalam aktivitas makan, mandi, berpakaian, perawatan diri, buang air besar, buang air kecil, toileting, mobilisasi, berpindah dan naik turun tangga. Metode penelitian ini adalah deskripsi kuantitatif. Teknik pengambilan sampel menggunakan accidentalsampling yaitu sebanyak 24 responden, penelitian ini dilakukan di Ruang 5 RSUD Dr. Soekardjo Kota Tasikmalaya. Instrumen penelitian yang digunakan adalah Barthel Index. Hasil penelitian menunjukkan status fungsional pasien stroke responden mayoritas memiliki ketergantungan total $(50,0 \%)$, dalam aktivitas makan mayoritas memerlukan bantuan, dalam aktivitas buang air besar mayoritas mandiri sedangkan dalam aktivitas mandi, berpakaian, perawatan diri, buang air kecil, toileting, mobilisasi, berpindah dan naik turun tangga mayoritas mengalami ketergantunga total. Berdasarkan hasil penelitian ini disimpulkan bahwa status fungsional pasien stroke mayoritas mengalami ketergantungan total.
\end{abstract}

Kata Kunci : Status fungsional, stroke 


\section{PENDAHULUAN}

Stroke merupakan penyebab kecacatan nomor satu dan penyebab kematian nomor dua di dunia.Dua pertiga stroke terjadi di Negara berkembang.Pada masyarakat barat, $80 \%$ penderita mengalami stroke iskemik dan $20 \%$ mengalami stroke hemoragik. Insiden stroke meningkat seiring pertambahan usia (Vika, Syarifah, \& Ratnawati, 2018).

Menurut Word Health Organization (WHO) (2011) 15 juta orang menderita stroke di seluruh dunia setiap tahunnya. Jumlah tersebut, 5 juta meninggal dan 5 juta lagi mengalami cacat permanen. Saat ini ada 4 juta orang di Amerika Serikat yang hidup dengan keterbatasan fisik akibat stroke, dan $15-30 \%$ diantaranya menderita cacat menetap (Wirasakti, 2013). Menurut WHO (2011) Indonesia telah menepati peringkat ke-97 di dunia untuk jumlah penderita stroke terbanyak dengan jumlah angka kematian mencapai 138.268 orang atau $9,70 \%$ dari total kematian yang terjadi pada tahun 2011 .

Menurut AmericanOf Neurology (2017), disabilitas umum yang sering terjadi pada pasien stroke adalah kelumpuhan atau kelemahan pada satu sisi tubuh (hemiplegia). Status fungsional atau kemampuan fungsional merupakan satu bagian kebutuhan fisiologis dalam kehidupan manusia. Pasien stroke pada umumnya cenderung memerlukan bantuan untuk dapat beraktivitas dan melakukan perawatan diri seperti mandi, toileting, makan, minum bejalan maupun berpindah tempat (Junaidi, 2011).

Menurut American Of Neurology (2017), disabilitas umum yang sering terjadi pada pasien stroke adalah kelumpuhan atau kelemahan pada satu sisi tubuh (hemiplegia). Status fungsional atau kemampuan fungsional merupakan satu bagian kebutuhan fisiologis dalam kehidupan manusia. Pasien stroke pada umumnya cenderung memerlukan bantuan untuk dapat beraktivitas dan melakukan perawatan diri seperti mandi, toileting, makan, minum bejalan maupun berpindah tempat (Junaidi, 2011).

Berdasarkan hasil studi pendahuluan yang dilakukan di Ruang 5 RSUD Dr. Soekardjo Kota Tasikmalaya dari 4 pasien stroke 3 diantaranya mengalami penurunan kesadaran dengan ketergantungan total dan satu pasien mengalami hemiplegia pada ekstermitas sebelah kanan serta mengalami gangguan bicara dengan fungsi tubuh yang rendah. pemeriksaan status fungsional sangat penting untuk dilakukan sehingga dapat dijadikan acuan dalam menentukan tindakan yang tepat dan perawatan spesifik yang dapat memberikan pengaruh besar terhadap kehidupan pasien. Hal inilah yang menyebabkan peneliti tertarik untuk melakukan penelitian tentang status fungsional pasien stroke.

Berdasarkan latarbelakang diatas, penelitian ini bertujuan untuk mengetahui gambaran status fungsional pasien stroke di Ruang 5 RSUD Dr. Soekardjo Kota Tasikmalaya.

\section{METODE PENELITIAN}

Penelitian ini merupakan penelitian kuantitatif deskriptif-eksploratif yang bertujuan menggambarkan status fungsional pasien stroke Ruang 5 RSUD Dr. Soekardjo Kota Tasikmalaya. Subyek penelitian ini adalah pasien stroke yang di rawat inap di Ruang 5 RSUD Dr. Soekardjo Kota Tasikmalaya dengan teknik sampling accidental sampling Instrumen yang digunakan skala penilaian Barthel Indeks .

\section{HASIL PENELITIAN}

\section{Karakteristik Responden}

Berikut ini karakteristik responden berdasarkan jenis kelamin dan usia. 
Table 1

Distribusi Frekuensi Responden Berdasarkan Jenis Kelamin Pasien Stroke.

\begin{tabular}{ccc}
\hline $\begin{array}{c}\text { Jenis } \\
\text { kelamin }\end{array}$ & Jumlah & Persen \\
\hline Laki-laki & 12 & $50 \%$ \\
Perempuan & 12 & $50 \%$ \\
\hline Total & $\mathbf{2 4}$ & $\mathbf{1 0 0}$ \\
\hline
\end{tabular}

Berdasarkan data diatas diketahui bahwa responden laki laki dan perempuan memiliki kesamaan jumlah yaitu dengan jumlah laki-laki sebanyak 12 orang $(50 \%)$ dan perempuan sebanyak 12 orang $(50 \%)$ dari total responden 24 orang.

Tabel 2

Distribusi Frekuensi Responden Berdasarkan Usia Pasien Stroke

\begin{tabular}{ccc}
\hline Usia ( Tahun) & Jumlah & Persen \\
\hline$<45$ tahun & 1 & $4,2 \%$ \\
$45-65$ tahun & 11 & 45,8 \\
$>65$ tahun & 12 & 50,0 \\
\hline Total & 24 & $100 \%$ \\
\hline
\end{tabular}

Berdasarkan tabel diatas diketahui bahwa dari 24 orang responden mayoritas berada pada kisaran usia di atas 65 tahun sebanyak 12 orang $(50,0 \%)$.

\section{Hasil Penelitian}

Berikut ini hasil penelitian dari variabel yang diteliti.

\section{Tabel 3}

Distribusi Frekuensi Status Fungsional Pasien Stroke

\begin{tabular}{lll}
\hline \multicolumn{1}{c}{\begin{tabular}{c}
\multicolumn{1}{c}{ Status } \\
Fungsional
\end{tabular}} & Jumlah & Persen \\
\hline $\begin{array}{l}\text { Mandiri } \\
\text { Ketergantungan } \\
\text { ringan }\end{array}$ & 0 & 0 \\
$\begin{array}{l}\text { Ketergantungan } \\
\text { sedang }\end{array}$ & 3 & 12,5 \\
Ketergantungan & 8 & 33,3 \\
\hline
\end{tabular}

\begin{tabular}{l}
\hline $\begin{array}{l}\text { berat } \\
\text { Ketergantungan } \\
\text { total }\end{array}$ \\
Total \\
\multicolumn{1}{c}{$\mathbf{2 4} \mathbf{1 0 0 , 0}$} \\
Berdasarkan tabel diatas diketahui \\
bahwa status fungsional pasien stroke \\
yang dirawat di Ruang X RS Y \\
Tasikmalaya dari 24 responden mayoritas \\
mengalami ketergatungan total yaitu \\
berjumlah 13 orang $(54,2 \%)$.
\end{tabular}

Tabel 4

Distribusi Frekuensi Status Fungsional Pasien Stroke Dalam Aktifitas Makan

\begin{tabular}{lll}
\hline \multicolumn{1}{c}{$\begin{array}{c}\text { Status } \\
\text { fungsional }\end{array}$} & Jumlah & Persen \\
\hline $\begin{array}{l}\text { Mandiri } \\
\text { Memerlukan }\end{array}$ & 3 & 12,5 \\
$\begin{array}{l}\text { bantuan } \\
\text { Ketergantungan } \\
\text { total }\end{array}$ & 7 & 58,3 \\
\hline Total & $\mathbf{2 4}$ & $\mathbf{1 0 0 , 0}$ \\
\hline
\end{tabular}

Berdasarkan tabel diatas diketahui bahwa status fungsional dalam aktivitas makan mayoritas memerlukan bantuan dengan jumlah 14 orang $(58,3)$.

Tabel 5

Distribusi Frekuensi Status Fungsional Pasien Stroke Dalam Aktifitas Mandi

\begin{tabular}{|c|c|c|}
\hline $\begin{array}{c}\text { Status } \\
\text { fungsional }\end{array}$ & Jumlah & Persen \\
\hline Mandiri & 0 & 0 \\
\hline $\begin{array}{l}\text { Memerlukan } \\
\text { bantuan }\end{array}$ & 3 & 12,5 \\
\hline $\begin{array}{l}\text { Ketergantungan } \\
\text { total }\end{array}$ & 21 & 87,5 \\
\hline Total & 24 & 100,0 \\
\hline \multicolumn{3}{|c|}{$\begin{array}{l}\text { Berdasarkan tabel diatas diketahui } \\
\text { bahwa status fungsional dalam aktivitas } \\
\text { mandi mayoritas } \\
\text { ketergantungan total dengan jumlah } 21 \\
\text { orang }(87,5) \text {. }\end{array}$} \\
\hline
\end{tabular}


Tabel 6

Distribusi Frekuensi Status Fungsional Pasien Stroke Dalam Aktifitas Berpakaian

\begin{tabular}{cll}
\hline $\begin{array}{c}\text { Status } \\
\text { fungsional }\end{array}$ & Jumlah & Persen \\
\hline $\begin{array}{c}\text { Mandiri } \\
\text { Memerlukan } \\
\text { bantuan }\end{array}$ & 10 & 4,2 \\
$\begin{array}{c}\text { Ketergantungan } \\
\text { total }\end{array}$ & 13 & 54,7 \\
\hline Total & 24 & 100,0 \\
\hline
\end{tabular}

Berdasarkan tabel diatas diketahui bahwa status fungsional dalam aktivitas berpakaian mayoritas mengalami ketergantungan total dengan jumlah 13 orang $(54,2 \%)$.

Tabel 7

Distribusi Frekuensi Status Fungsional Pasien Stroke Dalam Aktifitas Perawatan Diri

\begin{tabular}{cll}
\hline $\begin{array}{c}\text { Status } \\
\text { fungsional }\end{array}$ & Jumlah & Persen \\
\hline $\begin{array}{c}\text { Mandiri } \\
\text { Memerlukan } \\
\text { bantuan } \\
\text { Ketergantungan } \\
\text { total }\end{array}$ & 0 & 0 \\
\hline Total & 10 & 41,7 \\
\hline
\end{tabular}

Berdasarkan tabel diatas diketahui bahwa status fungsional dalam aktivitas perawatan diri mayoritas mengalami ketergantungan total dengan jumlah 14 orang $(58,3 \%)$.

Tabel 8

Distribusi Frekuensi Status Fungsional Pasien Stroke Dalam Aktifitas Buang Air Besar

\begin{tabular}{cll}
\hline $\begin{array}{c}\text { Status } \\
\text { fungsional }\end{array}$ & Jumlah & Persen \\
\hline Mandiri & 17 & 70,8 \\
Memerlukan & 0 & 0 \\
\hline
\end{tabular}

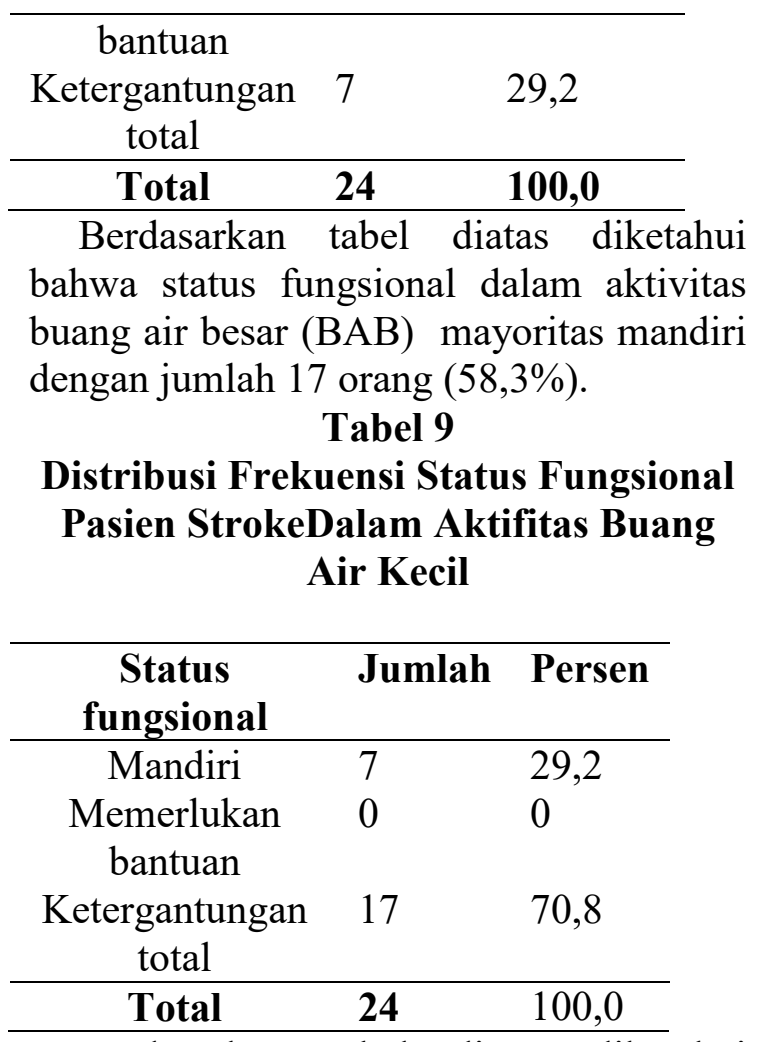

Berdasarkan tabel diatas diketahui bahwa status fungsional dalam aktivitas buang air kecil (BAK) mayoritas ketergantungan total dengan jumlah 17 orang $(70,8 \%)$.

Tabel 10

Distribusi Frekuensi Status Fungsional Pasien StrokeDalam Aktifitas Toileting

\begin{tabular}{cll}
\hline Status fungsional & Jumlah & Persen \\
\hline Mandiri & 0 & 0 \\
$\begin{array}{c}\text { Memerlukan } \\
\text { bantuan }\end{array}$ & 4 & 16,7 \\
$\begin{array}{c}\text { Ketergantungan } \\
\text { total }\end{array}$ & 20 & 83,3 \\
\hline Total & 24 & 100,0 \\
\hline
\end{tabular}

Berdasarkan tabel diatas diketahui bahwa status fungsional dalam aktivitas toileting mayoritas mengalami ketergantungan total dengan jumlah 20 orang $(83,3)$. 


\section{Tabel 11 \\ Distribusi Frekuensi Status Fungsional Pasien StrokeDalam Aktifitas Berpindah}

\begin{tabular}{cll}
\hline Status fungsional & Jumlah & Persen \\
\hline Mandiri & 0 & 0 \\
$\begin{array}{c}\text { Memerlukan } \\
\text { bantuan }\end{array}$ & 11 & 45,8 \\
$\begin{array}{c}\text { Ketergantungan } \\
\text { total }\end{array}$ & 13 & 54,2 \\
\hline Total & $\mathbf{2 4}$ & $\mathbf{1 0 0 , 0}$ \\
\hline
\end{tabular}

Berdasarkan tabel diatas diketahui bahwa status fungsional dalam aktivitas berpindah mayoritas mengalami ketergantungan total dengan jumlah 13 orang $(54,2 \%)$.

Tabel 12

Distribusi Frekuensi Status Fungsional Pasien StrokeDalam Aktifitas Mobilisasi

\begin{tabular}{cll}
\hline $\begin{array}{c}\text { Status } \\
\text { fungsional }\end{array}$ & Jumlah & Persen \\
\hline $\begin{array}{c}\text { Mandiri } \\
\text { Memerlukan } \\
\text { bantuan }\end{array}$ & 0 & 0 \\
$\begin{array}{c}\text { Ketergantungan } \\
\text { total }\end{array}$ & 24 & 0 \\
\hline Total & $\mathbf{2 4}$ & $\mathbf{1 0 0 , 0}$ \\
\hline
\end{tabular}

Berdasarkan tabel diatas diketahui bahwa status fungsional dalam aktivitas mobilisai keseluruhan mengalami ketergantungan total dari 24 orang $(100,0 \%)$.

Tabel 13

Distribusi Frekuensi Status Fungsional Pasien StrokeDalam Aktifitas Naik Turun Tangga

\begin{tabular}{cll}
\hline $\begin{array}{c}\text { Status } \\
\text { fungsional }\end{array}$ & Jumlah & Persen \\
\hline Madiri & 0 & 0 \\
$\begin{array}{c}\text { Memerlukan } \\
\text { bantuan }\end{array}$ & 0 & 0 \\
\hline
\end{tabular}

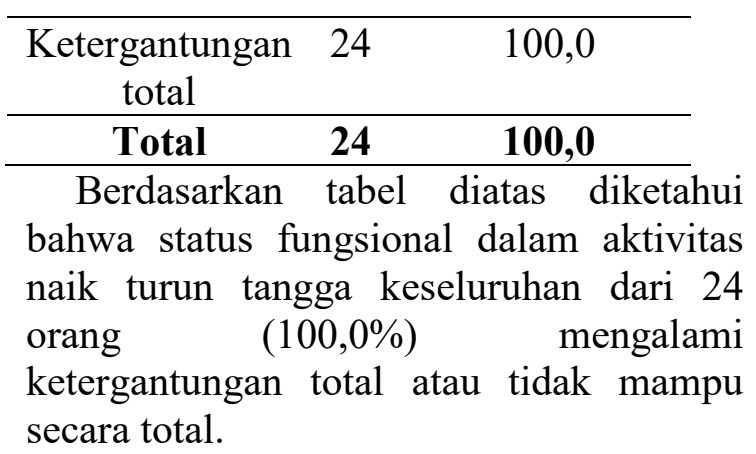

\section{PEMBAHASAN}

1. Status fungsional pasien strroke di Ruang X RS Y Tasikmalaya.

Penelitian yang telah dilakukan terhadap 24 responden didapatkan hasil bahwa distribusi status fungsional responden mayoritas adalah ketergantungan total dengan jumlah 13 orang $(54,2 \%)$, dari 13 orang tersebut 6 diantaranya mengalami penurunan kesadaran sehingga dalam menjalankan aktivitas sehari-hari membutuhkan bantuan orang lain.. Hal ini sesuai dengan penelitian yang dilakukan oleh Fandri et al., (2013) Status fungsional pasien stroke terbanyak adalah dependent total berjumlah 39 orang $(78.0 \%)$.

Ketidakmampuan ini dikarenakan penyakit stroke yang dialami dapat menyebabkan kelumpuhan motorik, karena kendali otak sebelah kanan bertugas menggerakkan tubuh bagian kiri begitupun sebaliknya. Hal ini biasanya menyebabkan pasien stroke sulit untuk melakukan gerakan tangan dan kaki dibagian otak yang terserang stroke, sehingga pasien membutuhkan bantuan orang lain (Fandri et al., 2013).

\section{Status fungsional dalam aktivitas makan \\ Penelitian yang telah dilakukan} terhadap 24 responden didapatkan hasil bahwa status fungsional berdasarkan aktifitas makan mayoritas memerlukan 
bantuan dengan jumlah 14 orang $(58,3 \%)$. Hal ini sesuai dengan penelitian yang dilakukan oleh Rahmano,dkk (2013) diketahui bahwa distribusi status fungsional responden berdasarkan aktifitas makan yang terbanyak adalah memerlukan bantuan dalam beberapa hal $40.0 \%$ dengan jumlah 12 responden dari total responden 30 orang.Pasien stroke mengalami disfagia, disfagia adalah keadaan yang dimana responden mengalami kesulitan menelan yang diakibatkan oleh gangguan peredaran darah otak, yang dapat menimbulkan tersedak minuman atau makanan yang tersangkut dalam trakhea atau bronkus (Agustari, 2011).

\section{Status fungsional pasien stroke dalam aktifitas mandi}

Penelitian yang telah dilakukan terhadap 24 responden didapatkan hasil bahwa status fungsional berdasarkan aktifitas mandi mayoritas mengalami ketergantungan total dengan jumlah 21 orang $(87,5)$. Pada hasil wawancara yang dilakukan dengan responden ketergantungan aktifitas ini meliputi membutuhkan keseluruhan bantuan seperti melepas baju, menggunakan sabun, mencuci rambut, tidak mampu memegang gayung, tidak mampu mengguyur air ke badan, tidak mampu menggosok dan membersihkan badan. Penelitian yang dilakukan oleh Rahmano,dkk (2013) diketahui bahwa distribusi status fungsional responden berdasarkan aktifitas mandi yang terbanyak adalah tidak dapat melakukan sendiri $80.0 \%$ dengan jumlah 24 responden.

Dalam melakukan aktifitas mandi perlu adanya kemampuan fungsi motorik, ketidakmampuan ini dikarenakan penyakit stroke yang dialami dapat menyebabkan kelumpuhan motorik, menyebabkan pasien stroke sulit untuk melakukan gerakan tangan dan kaki dibagian otak yang terserang stroke, sehingga pasien membutuhkan bantuan orang lain (Junaidi, 2011).

\section{Status fungsional pasien stroke dalam aktifitas berpakaian}

Penelitian yang telah dilakukan terhadap 24 responden didapatkan hasil bahwa status fungsional responden berdasarkan aktifitas berpakaian dengan jumlah 13 orang (54,2\%).Ketidakmampuan ini meliputi secara keseluruhan dalam berpakain, mengenakan dan melepaskan pakaian, menggunakan tali sepatu, membuka dan menutup reksleting, kancing, dan penyiapan pakaian.Hal ini sesuai dengan penelitian yang dilakukan oleh Rahmano,dkk (2013) diketahui dari 30 responden didapatkan hasil bahwa distribusi status fungsional responden berdasarkan aktifitas berpakaian yang terbanyak adalah tidak dapat melakukan sendiri dengan jumlah 13 responden (43.3\%). Hal ini terjadi karena, keterbatasnnya kemampuan motorik responden yang berupa kelumpuhan dan kelemahan. Efek defisit motoris ini juga meliputi rasa sakit, kelelahan, perubahan tonus otot (Davis \& Norrving, 2014).

\section{Status fungsional pasien stroke dalam aktifitas perawatan diri}

Penelitian yang telah dilakukan terhadap 24 responden didapatkan hasil bahwa status fungsional responden berdasarkan aktifitas perawatan diri mayoritas mengalami ketergantungan total dengan jumlah 14 orang (58,3\%). Ketidakmampuan ini berupa kesulitan menggerakan tangan untuk melakukaaktifitas seperti menggosok gigi, mencuci muka dan menyisir atau berdandan.

Berbeda dengan penelitian yang dilakukan oleh Rahmano,dkk (2013) diketahui dari 30 responden didapatkan hasil bahwa distribusi status fungsional responden berdasarkan aktifitas kebersihan diri yang terbanyak adalah memerlukan bantuan dengan jumlah 17 
responden (56.7\%). Dalam melakukan aktifitas kebersihan diri memerlukan keseimbangan antara kemampuan motorik, persepsi dan kognitif.

\section{Status fungsional pasien stroke dalam aktifitas buang air besar (Bowel)}

Penelitian yang telah dilakukan terhadap 24 responden didapatkan hasil bahwa status fungsional responden berdasarkan aktifitas buang air besar mayoritas mandiri dengan jumlah 17 orang (70,8\%). Berdasarkan hasil wawancara, responden cenderung mengatakan masih dapat merasakan kontrol pada saat ingin defekasi. Penelitian yang telah dilakukan oleh Rahmano,dkk (2013) terhadap 30 responden didapatkan hasil bahwa distribusi status fungsional responden berdasarkan aktifitas defekasi yang terbanyak adalah tidak terjadi inkotinensia dengan jumlah 19 orang responden $(63.3 \%)$.

Lingga (2013) mengatakan bahwa, hilangnya kemampuan sensorik dan motorik menyebabkan orang yang terkena stroke kehilangan kendali pada saat buang air besar.Sering kali penderita stroke mengeluarkan feses tanpa merasakan keinginan apapun sebelumnya.Kondisi ini hanya bersifat sementara, namun jika kerusakan motorik sudah parah bisa berlangsung permanen.Hal ini tergantung seberapa besar dampak stroke terhadap kerusakan otak yang dialaminya (Lingga, 2013).

\section{Status fungsional pasien stroke dalam aktifitas buang air kecil ( Bladder)}

Penelitian yang telah dilakukan terhadap 24 responden didapatkan hasil bahwa status fungsional responden berdasarkan aktifitas buang air kecil mayoritas adalah ketergantungan total dengan jumlah 17 orang (70,8\%) dengan pemasangan dower kateter. Berbeda dengan penelitian yang dilakukan oleh
Rahmano dkk (2013) terhadap 30 responden didapatkan hasil bahwa distribusi status fungsional responden berdasarkan aktifitas miksi yang terbanyak adalah tidak terjadi inkotinensia dengan jumlah 16 responden (53.3\%).

Hilangnya kemampuan sensorik dan motorik menyebabkan insan pasca stroke kehilangan kendali pada saat akan berkemih dan atau buang air besar. Kerap sekali mereka ngompol atau tiba-tiba sudah mengeluarkan feses tanpa merasakan keinginan apapun sebelumnya. Kondisi seperti ini biasanya hanya bersifat sementara saja, namun jika kerusakan motorik sudah parah bisa berlangsung permanen.Ihwal tentang ini bergantung seberapa besar dampak stroke terhadap kerusakan otak yang dialaminya, hal ini lebih banyak terjadi pada lansia yang mengalami stroke.Faktor umur juga menjadi faktor terjadinya inkontinensia urin (Lingga, 2013).

\section{Status fungsional pasien stroke dalam aktifitas toileting}

Penelitian yang telah dilakukan terhadap 24 responden didapatkan hasil bahwa status fungsional responden berdasarkan aktifitas penggunaan toilet mayoritas adalah ketergantungan total dalam toileting dengan jumlah 20 orang $(83,3 \%)$. Berbeda dengan penelitian yang telah dilakukan oleh Rahmano,dkk (2013) terhadap 30 responden didapatkan hasil bahwa distribusi status fungsional responden berdasarkan aktifitas penggunaan toilet yang terbanyak adalah memerlukan bantuan dengan jumlah 15 responden $(50.0 \%)$.

Dalam penggunaan toilet memerlukan keseimbangan dalam melakukan kemampuan motorik. Lingga (2013) mengatakan bahwa stroke umumnya ditandai dengan cacat pada salah satu sisi tubuh (hemiplegi), jika dampaknya tidak terlalu parah hanya menyebabkan anggota 
tubuh tersebut menjadi tidak bertenaga (hemiparesis). Hal tersebut juga menyulitkan pasien dalam aktifitas berjalan ke toilet dan membersihkan area genetalia.

\section{Status fungsional pasien stroke dalam aktifitas berpindah (transfer)}

Penelitian yang telah dilakukan terhadap 24 responden didapatkan hasil bahwa status fungsional responden berdasarkan aktifitasaktifitas berpindah atau transfer yang mayoritas mengalami ketergantungan total atau tidak mampu untuk dapat duduk di tempat tidur atau berpindah ke kursi roda dengan jumlah 13 orang ( 54,3\%). Aktifitas ini dilakukan terutama pada saat pasien akan melakukan tindakan pemeriksaan seperti foto rontgen, terkecuali pasien yang mengalami penurunan kesadaran. Hal ini berbeda dengan penelitian yang telah dilakukan oleh Rahmano,dkk (2013) terhadap 30 responden didapatkan hasil bahwa distribusi status fungsional responden berdasarkan aktifitas transfer yang terbanyak adalah perlu bantuan dengan jumlah 13 responden (43.3\%).

Pada pasien stroke terjadinya functional limitation yang timbul adalah terjadi penurunan kemampuan motorik fungsional. Penurunan kemampuan dalam melakukan aktifitas dari tidur terlentang seperti mampu melakukan gerakan tangan dan kaki secara aktif saat miring, terlentang duduk disamping bed seperti mampu melakukan gerakan menggangkał. kepala namun saat menurunkan kaki butuh bantuan orang lain agar mampu duduk disamping bed, keseimbangan duduk seperti kurang mampu mempertahankan keseimbangan duduk, dari duduk ke berdiri seperti masih membutuhkan bantuan orang lain, berjalan seperti masih membutuhkan bantuan dari orang lain.

Status fungsional pasien stroke dalam aktifitas mobilisasi
Penelitian yang telah dilakukan terhadap 24 responden didapatkan hasil bahwa status fungsional responden berdasarkan aktifitas mobilitas yang terbanyak adalah ketergantungan total yaitu sebanyak 24 orang $(100,0 \%)$. Berbeda dengan penelitian yang telah dilakukan oleh Rahmano,dkk (2013) terhadap 30 responden didapatkan hasil bahwa distribusi status fungsional responden berdasarkan aktifitas mobilitas yang terbanyak adalah berjalan dengan bantuan dengan jumlah 13 responden $(43.3 \%)$.

Mobilisasi merupakan suatu aktifitas kompleks yang memerlukan tidak hanya kekuatan otot, tetapi juga kemampuan kognitif, persepsi, keseimbangan dan koordinasi.Responden cenderung tidak mampu melakukan mobilisasi lebih dari 5 meter.

Ketidakmampuan ini dikarenakan penyakit stroke yang dialami dapat menyebabkan kelumpuhan motorik, menyebabkan pasien stroke sulit untuk melakukan gerakan tangan dan kaki dibagian otak yang terserang stroke, sehingga pasien membutuhkan bantuan orang lain.Selain itu penurunan kemampuan dapat terjadi dikarenakan penurunan kesadaran serta daerah otak tertentu tidak berfungsi yang disebabkan oleh terganggunya aliran darah ke tempat tersebut atau pecahnya pembuluh darah pada tempat tersebut.

\section{Status fungsional pasien stroke dalam aktifitas naik turun tangga}

Penelitian yang telah dilakukan terhadap 24 responden didapatkan hasil bahwa status fungsional responden berdasarkan aktifitas naik turun tangga di dapatkan hasil secara keseluruhan dari 24 orang $\quad(100,0 \%) \quad$ mengalami ketidakmampuan total. Gangguan sensoris dan motorik paska stroke mengakibatkan gangguan keseimbangan termasuk kelemahan otot, penurunan fleksibilitas 
jaringan lunak, serta gangguan kontrol motorik dan sensorik.Fungsi yang hilang akibat gangguan kontrol motorik pada pasien stroke mengakibatkan hilangnya koordinasi, hilangnya kemampuan keseimbangan tubuh dan postur (kemampuan untuk mempertahankan posisi tertentu) (Junaidi, 2011).

Naik dan turun tangga, tidak akan dapat dilakukan oleh orang yang mengalami kelumpuhan total. Hal yang dilakukan oleh orang paska stroke yang menderita kelumpuhan total adalah berpegangan pada orang yang ada di sekitar. Tidak hanya itu, tangan yang sehat biasanya digunakan untuk berpegangan pada pegangan tangga.Tangan ini dijadikan tumpuan bagi orang tersebut.

Pada hasil wawancara yang dilakukan dengan responden, ketidakmandirian yang dialami responden dikarenakan responden malas atau hilang minat terhadap kegiatan atau aktivitas. Selain itu, keluarga juga tidak membiarkan responden beraktivitas sendiri

\section{KESIMPULAN}

Setelah melaksanakan penelitian mengenai status fungsional pasien stroke di Ruang X RS Y Tasikmalaya, maka dapat disimpulkan bahwa status fungsional pasien stroke di Ruang $\mathrm{X}$ RS Y Tasikmalaya mayoritas mengalami ketergantungan total.

Status fungsional pasien stroke dalam aktifitas makan mayoritas 58,3 \% membutuhkan bantuan, status fungsional dalam aktifitas mandi yang mayoritas $87,5 \%$ mengalami ketergantungan total. status fungsional dalam aktifitas berpakaian mayoritas $54,2 \%$ mengalami ketergantungan total,status fungsional dalam aktifitas perawatan diri mayoritas $58,3 \%$ mengalami ketergantungan total, status fungsional dalam aktifitas $\mathrm{BAB}$ mayoritas $\quad 70,8 \%$ mandiri, status fungsional dalam aktifitas BAK mayoritas $70,8 \%$ mengalami ketergantungan total, status fungsional dalam aktifitas penggunaan toilet mayoritas $83,3 \%$ mengalami ketergantungan total, status fungsional dalam aktifitas berpindah mayoritas $\quad 54,2 \% \quad$ mengalami ketergantungan total, status fungsional dalam aktifitas mobilisasi keseluruhan $100,0 \%$ mengalami ketergantungan total, status fungsional dalam aktifitas naik turun tangga keseluruhan 100,0 \% mengalami ketergantungan total.

\section{SARAN}

Penelitian ini dapat memberikan informasi bagi pasien dan keluarga dalam meningkatkan kesehatan paska stroke dan melakukan aktifitas sesuai dengan kemampuan status fungsional yang dimiliki pasien dengan dilakukan secara mandiri seperti latihan ROM aktif atau pasif.

\section{DAFTAR PUSTAKA}

Abbott, C., Abidi, S. R., Abrahamson, D., Trninic, D., Gutiérrez, J., Huth, J., ... Rothrock, J. F. (2010). Teamworking guide for primary healthcare. Stroke. https://doi.org/10.4300/JGME-D-11-

00221.1

Bakara, D. M., \& Warsito, S. (2016). Latihan Range Of Motion (ROM) Pasif Terhadap Rentang Sendi Pasien Pasca Stroke. VII(2), 12-18.

Béjot, Y., Delpont, B., \& Giroud, M. (2016). Rising Stroke Incidence in Young Adults: More Epidemiological Evidence, More Questions to Be Answered. Journal of the American Heart Association. https://doi.org/10.1161/jaha.116.003661

Carare, R. O., \& Kalaria, R. (2016). Cerebrovascular pathology: the dark side of neurodegeneration. Acta Neuropathologica. https://doi.org/10.1007/s00401-016-1573- 
Healthcare Nursing Journal Fakultas Ilmu Kesehatan UMTAS

E-ISSN : 2655-6812, Volume 2 Nomor 1, Agustus 2019

http://journal.umtas.ac.id/index.php/healtcare

$\mathrm{X}$

Davis, S., \& Norrving, B. (2014). World Stroke Day 2014: "I am Woman." International Journal of Stroke. https://doi.org/10.1111/ijs.12370

Depkes RI. (2013). Riset Kesehatan Dasar (RISKESDAS) 2013. Laporan Nasional 2013. https://doi.org/1 Desember 2013

Emzir, M., \& Pd, M. (2012). Metodologi Penelitian Kualitatif Analisis data. Jakarta: Raja Grafindo.

Fandri, S.-., Utomo, W.-., \& Dewi, A. P. (2014). Perbedaan Status Fungsional Pasien Stroke Saat Masuk dan Keluar Ruang Rawat Inap RS Arifin Achmad. Jurnal Online Mahasiswa Program Studi Ilmu Keperawatan Universitas Riau.

Fandri, S., Utomo, W., Dewi, A. P., Studi, P., Keperawatan, I., \& Riau, U. (2013). Perbedaan Status Fungsional Pasien Stroke Saat Masuk Dan RS Arifin Achmad. 1-8.

Hanum, P., Lubis, R., \& Rasmaliah. (2017). Hubungan Karakteristik dan Dukungan Keluarga Lansia dengan Kejadian Stroke pada Lansia Hipertensi di Rumah Sakit Umum Pusat Haji Adam Malik Medan. Jurnal Jumantik, 3(1), 7288.

Junaidi, I. (2011). Stroke waspadai ancamannya. Yogyakarta: Penerbit Andi. https://doi.org/10.1176/appi.ajp.162.2.383

Latifah, L. (2016). Pemenuhan Kebutuhan Activities of Daily Living (Adl) Pasien Stroke Oleh Perawat Di Rumah Sakit Pku Muhammadiyah Yogyakarta Dan Gamping. 10-25. https://doi.org/10.1007/s13398-014-01737.2
National Institute of Neurological Disorders and Stroke. (2017). Autism Spectrum Disorder Fact Sheet | National Institute of Neurological Disorders and Stroke. National Institute of Neurological Disorders and Stroke. https://doi.org/10.1109/TIE.2009.2038338

Notoatmodjo, S. (2014). Ilmu Perilaku Kesehatan. In Rineka Cipta. https://doi.org/10.1103/PhysRevLett.106.2 11803

Nursalam. (2015). Metodelogi penelitian keperawatan. Pendekatan Praktis.Jakarta:

Salemba Medika.

Qureshi, I. A., \& Mehler, M. F. (2010). Emerging Role of Epigenetics in Stroke Part 1: DNA Methylation and Chromatin Modifications. ARCHIVES OF NEUROLOGY.

https://doi.org/10.1001/archneurol.2010.27 5

Ropyanto, C. ., Sitorus, \& Eryando. (2013). Analisis Faktor-Faktor Yang Berhubungan Dengan Status Fungsional Paska Open Reduction Internal Fixation (Orif) Fraktur Ekstremitas. Jurnal Keperawatan Medikal Bedah.

Setiadi. (2007). Konsep Dan Penulisan Riset Keperawatan. ;2007. In Graha Ilmu : Yogyakarta. https://doi.org/10.1186/14712105-8-89

Soetjiningsih, Maulana, H. D., Foscht, T., Angerer, T., Swoboda, B., Notoadmojo S, ... Bambang, M. A. W. (2012). Metode Penelitian Kesehatan. Qualitative Marktforschung. https://doi.org/10.1007/978-3-8349-94417_16

Sugiyono. (2013). Metode Penelitian Manajemen. Alfabeta. 
Healthcare Nursing Journal Fakultas Ilmu Kesehatan UMTAS

E-ISSN : 2655-6812, Volume 2 Nomor 1, Agustus 2019

http://journal.umtas.ac.id/index.php/healtcare

https://doi.org/10.1177/004057368303900

411

Udani, G., Studi, P., Politeknik, K., Tanjungkarang, K., Angka, P., Sakit, R., \& Moeloek, A. (2013). Faktor Resiko Kejadian Stroke. Jurnal Kesehatan Metro Sai Wawai Volume.

Valante, R., Blimhena, I., Miglne, E., Millers, A., Balodis, A., \& Pucite, E. (2015). Ischemic Stroke Due to Middle Cerebral Artery M1 Segment Occlusion: Latvian Stroke Register Data. Proceedings of the Latvian Academy of Sciences, Section B: Natural, Exact, and Applied Sciences. https://doi.org/10.1515/prolas2015-0042

Vika, W. N., Syarifah, A. S., \& Ratnawati, M. (2018). HUBUNGAN STATUS FUNGSIONAL DENGAN TINGKAT DEPRESI PADA PASIEN STROKE DI RUANG FLAMBOYAN RS JOMBANG. Jurnal Ilmiah Kebidanan (ScientificJournal of Midwifery). https://doi.org/10.33023/jikeb.v4i1.156

Wirawan, R. P. (2009). Rehabilitasi Stroke pada pelayanan kesehatan primer. Maj Kedokt

Indon. 
Healthcare Nursing Journal Fakultas Ilmu Kesehatan UMTAS

E-ISSN : 2655-6812, Volume 2 Nomor 1, Agustus 2019

http://journal.umtas.ac.id/index.php/healtcare 